\title{
PERANCANGAN DAN SIMULASI PENERAPAN VIRTUAL PRIVATE NETWORK MENGGUNAKAN METODE PPTP (Studi Kasus Pada PT Pelindo IV Makassar)
}

\author{
Muhammad Arafah ${ }^{1}$, Agung Gunawan ${ }^{2}$ \\ Teknik Informatika ${ }^{1,2}$, STMIK AKBA \\ arafah@akba.ac.id ${ }^{1}$, agung.one94@gmail.com ${ }^{2}$
}

\begin{abstract}
ABSTRAK
Penggunaan Virtual Private Networksebagai salah satu solusi untuk membangun jalur jaringan komunikasi yang aman client dan remote server melalui jaringan public.Penelitian ini bertujuan untuk meracang dan mengimplementasikan Virtual Private Network dengan menggunakan Metode Point to Point Tunneling Protocol (PPTP) pada PT Pelindo IV Makassar.Data ini diperoleh melalui (1) Penelitian Lapangan (2) Penelitian Pustaka (3) wawancara. Data dianalisis dengan menggunakan meotde PIECES (Performance, Information, Economic, Control, Efficiency dan Service). Hasil penelitian ini menunjukkan bahwa virtual private network menggunakan metode PPTP ini dapat diterapkan dengan baik.
\end{abstract}

\section{Keywords: Jaringan Komputer, Virtual Private Network, PPTP}

\section{Pendahuluan}

Perkembangan teknologi komunikasi dan infrastruktur jaringan untuk terus dikembangkan mengikuti jaringan Internetworking yang saat ini semakin berkembang. Pentingnya komunikasi dan informasi yang cepat dan sesuai dengan kebutuhan end-user merupakan prioritas dari komunikasi yang saat ini mulai mengarah ke penggunaan teknologi berbasis NGN (Next Generation Network) atau disebut dengan jaringan di masa yang akan datang dan juga era SDN (Software Defined Networking).

Banyaknya jaringan yang saling berkomunikasi mulai dari telepon, komputer, smartphone, dan perangkat jaringan lainnya menjadi hal yang semakin sulit terkendali, dan kerentanan bagi keamanan dan privasi lembaga, perusahaan swasta, maupun negeri di publik. Teknologi yang saat ini telah berkembang adalah teknologi virtual private network sebagai salah satu teknologi yang banyak digunakan sebagai solusi jaringan private yang aman.

Virtual Private Network merupakan saluran komunikasi private yang dibuat melalui jaringan internet, komunikasi yang menggunakan tunneling sebagai jalur komunikasi yang aman antara client dan remote server yanpg telah disiapkan. Pada penelitian ini penulis akan menggunakan PPTP (Point to Point Tunneling Protocol) sebagai metode yang digunakan untuk melakukan tunneling terhadap jaringan private melalui jaringan public dan masuk kembali ke jaringan private.

\section{Landasan Teori}

\subsection{Pengertian Virtual Private Network}

Virtual Private Network disingkat VPN merupakan metode aman untuk mengakses jaringan private melalui 
jaringan public secara aman dan menggunakan transmisi yang ter-enkripsi secara pribadi.

Menurut (Afrianto 2014) Virtual Private Network (VPN) adalah sebuah teknologi komunikasi yang memungkinkan untuk dapat terkoneksi ke jaringan publik dan menggunakannya untuk bergabung dengan jaringan lokal. Dengan cara tersebut maka akan didapatkan hak dan pengaturan yang sama seperti halnya berada didalam kantor atau network itu sendiri, walaupun sebenarnya menggunakan jaringan milik public.

Menurut (Hutapea, 2013:5) Secara umum, VPN adalah sebuah proses dimana jaringan umum (public network/ internet) diamankan untuk mengfungsikannya sebagaimana private network. Sebuah VPN tidak didefinisikan oleh rangkaian khusus atau rute, yaitu didefinisikan oleh mekanisme keamanan dan prosedurprosedur yang hanya mengizinkan pengguna-pengguna yang ditunjuk akses ke VPN dan informasi yang mengalir melaluinya.

\subsection{Implementasi VPN}

1. Remote Access VPN

Remote Access Virtual Private Network atau biasa disebut dengan istilah VPDN (Virtual Private Dial-Up Network), ini digunakan oleh perusahaan agar beberapa orang yang terhubung dari luar perusahaan dengan jarak yang jauh.Pada dasarnya VPN tipe ini digunakan jika administrator jaringan digunakan oleh pihak ketiga, sehingga dapat diakses diluar jaringan, agar dapat terhubung ke jaringan lokal perusahaan tersebut.

Perusahaan yang ingin menggunakan VPN jenis ini biasanya bekerjasama dengan ESP (Enterprise Service
Provider). ESP akan memberikan NAS

(Network Access Server) bagi perusahaan tersebut, agar pegawai perusahaan tersebut yang ingin mengakses jaringan lokal, harus terhubung dengan NAS dengan mendial nomor yang telah ditentukan.

\section{Site-to-Site VPN}

Site to Site VPN Merupakan Implementasi VPN antara cabang dan pusat dengan jarak yang berjauhan atau menghubungkan perusahaan dengan mitra kerja seperti supplier, pelanggan dan lain sebagainya. implementasi VPN untuk menghubungkan antara kantor pusat dan kantor cabang di sebut dengan intranet site-to site VPN, sedangkan yang menghubungkan dengan mitra kerja atau badan yang diluar bagian kantor disebut dengan ekstranet site-to-site VPN

\subsection{Topologi Jaringan}

Menurut (Syafrizal 2005:39) Topologi jaringan atau arsitektur jaringan adalah gambaran perencanaan hubungan antar komputer dalam Local Area Network yang umumnya menggunakan media kabel sebagai media transmisi dengan konektor, Ethernet Card, dan perangkat pendukung lainnya.

Ada beberapa jenis Topologi yang terdapat pada hubungan komputer pada jaringan lokal seperti :

1. Topologi Bus

Topologi Bus merupakan Bentangan Sebuah Kabel yang kedua ujungnya ditutup, dimana sepanjang kabel terdapat node-node.Signal dalam kabel dengan topologi ini dilewati satu arah sehingga memungkinkan sebuah collision terjadi. 
2. Topologi Ring

Topologi jaringan yang berupa lingkaran tertutup yang berisi nodenode. Signal mengalir dalam dua arah sehingga dapat menghindarkan terjadinya collision sehingga memungkinkan terjadinya pergerakan data yang sangat cepat

3. Topologi Star

Karakteristik dari jaringan ini adalah node (station) berkomunikasi langsung dengan station lain melalui central node (Hub/Switch), Traffic data mengalir dari node ke central node dan diteruskan ke node (station) tujuan. Jika salah satu segmen kabel putus, jarigan lain tidak terputus.

\subsection{Point to Point Tunneling Protocol}

Menurut (Saputro 2012) PPTP Merupakan protocol jaringan yang memungkingkan pengamanan transfer data dari remote client (Client yang berada jauh dari server) ke server pribadi perusahaan dengan membuat sebuah VPN melalui TCP/IP. Protokol ini dikembangkan oleh Microsoft dan Cisco.

Menurut (Towidjojo 2013) Untuk Menerapkan tunneling, paket daya yang dibungkus menjadi paket data lain (encapsulation). Untuk melakukan pembungkusan data tadi digunakanlah protocol lain yang memang dirancang untuk melakukan encapsulation.

PPTP merupakan protocol jaringan yang mengubah paket PPP menjadi IP Datagram agar dapat ditrasnmisikan melalui Internet.PPTP juga dapat digunakan dalam jaringan Private LAN to LAN. Fasilitas Utama dari Penggunaan PPTP adalah dapat digunakannya PSTN (Public-Switched Telepohone Network untuk membangun VPN. Pembangunan
PPTP yang mudah dan berbiaya murah untuk digunakan secara luas menjadi solusi untuk remote user dan mobile user. Karena PPTP memberikan keamanan dan enkripsi komunikasi PSTN ataupun internet.

\section{Metodologi Penelitian}

\subsection{Analisis Kelemahan Sistem}

Pengembangan sistem informasi untuk proses rencana perawatan memerlukan analisis yang tepat untuk bisa memetakan terlebih dahulu masalah dan kelemahan pada sistem lama. Adapun metode yang bisa digunakan diantaranya metode PIECES (Performance, Information, Economic, Control, Efficiency dan Service).

\subsection{Analisis Kelayakan Sistem}

\section{Analisis Kelayakan Teknologi}

Teknologi yang digunakan untuk membangun VPN ini adalah teknologi PPTP yang di enkripsi dengan teknologi 128 bit encryption sehingga, penggunaan VPN sangat layak digunakan untuk mengintegrasikan jaringan di cabang dengan di pusat PT. Pelindo IV Makassar.

2. Analisis Kelayakan Operasional

Untuk operasional dengan menggunakan teknologi VPN, setiap cabang tidak perlu memiliki server sistem sendiri melainkan akan dipusatkan di kantor pusat, dan semua cabang akan mengakses ke pusat melaluii jalur VPN yang aman dengan metode tunneling PPTP. sehingga proses operasional akan lebih mudah dan lebih terorganisir ke satu sistem yang di integrasi melalui jalur komunikasi yang aman. 


\section{Analisis Kelayakan Ekonomi}

Dengan teknologi VPN, akan mengurangi pembelian server baru untuk cabang-cabang baru yang akan dibuka di masa depan. hanya cukup membangun jalur internet agar dapat terhubung ke server VPN melalui Tunneling PPTP. Dengan cara ini, akan mengurangi penggunaan biaya yang besar.

\subsection{Metode Perancangan Sistem}

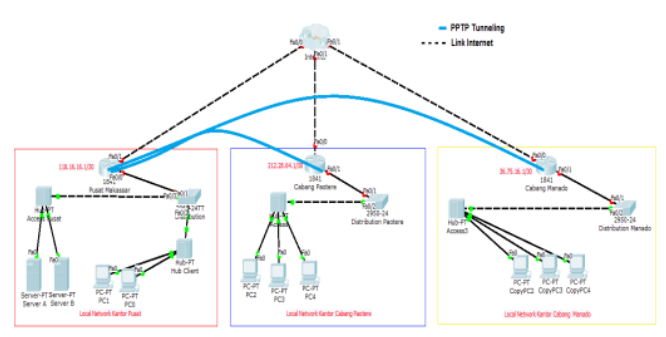

Gambar 1. Topologi Jaringan

\section{Kajian Pustaka}

\subsection{Hasil Implementasi}

Dalam penerapan VPN, diperlukan koneksi ke ISP di masing-masing kantor cabang dan pusat untuk memungkinkan terjadinya koneksi ke internet dengan menggunakan ISP yang berbeda-beda.

Perangkat jaringan yang digunakan di kantor pusat adalah perangkat cisco router 7200 Series Untuk melayani semua cabang-cabang di wilayah indonesia bagian timur.

Kemudian perangkat yang digunakan oleh cabang adalah perangkat Cisco Router 3650 Series yang akan memberikan fasilitas kepada kantor cabang untuk terhubung ke internet

\subsection{Topologi Pusat}

Pada Kantor Pusat, Perangkat akan dihubungkan ke internet dengan NAT standard dan VLAN disisi switch, ini memungkinkan beberapa network dapat berkomunikasi dalam jaringan internal kantor pusat.

Pada kantor pusat Pelindo IV Makassar, juga terdapat server SIMPAT yang merupakan server utama yang akan menjadi pusat akses seluruh cabangcabang melalui Virtual Private Network.

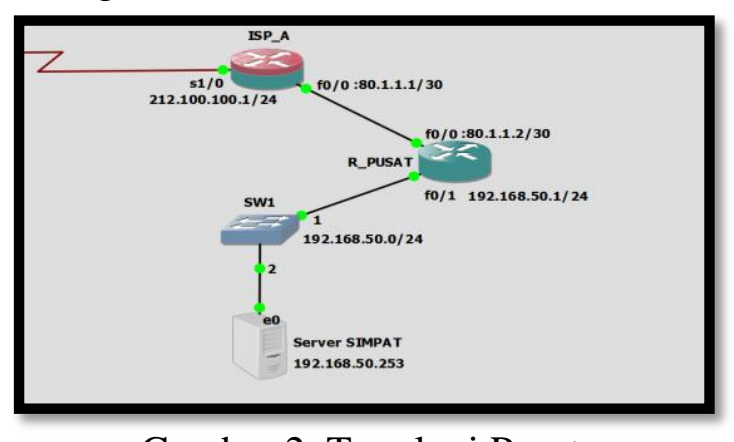

Gambar 2. Topologi Pusat

\subsection{Topologi Keseluruhan}

Client yang berada di cabang dapat langsung menggunakan jaringan private kantor pusat melalui jalur publik menggunakan Virtual Private Network. Penggunaan sistem yang baru akan lebih realtime karena data langsung terkirim ke kantor pusat Pelindo IV Makassar.

Dengan penggunaan VPN, kantor cabang tidak membutuhkan server untuk menampung informasi secara lokal di setiap cabang, dengan sistem yang baru, cabang hanya membutuhkan koneksi internet untuk terhubung ke server pusat agar dapat melakukan komputasi dengan sistem yang ada pada kantor pusat Pelindo IV Makassar.

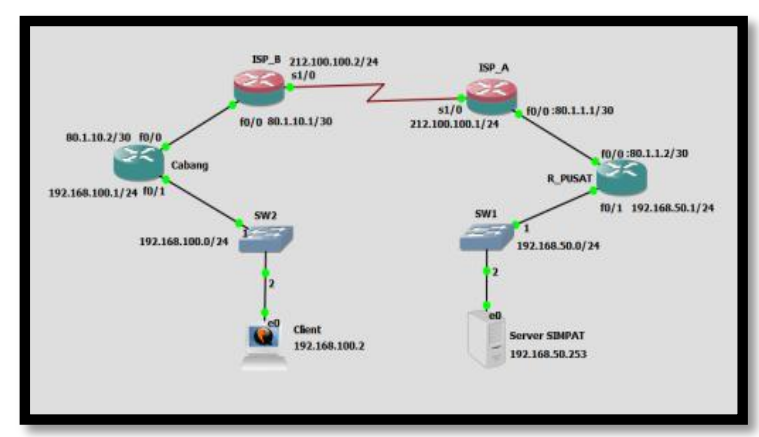

Gambar 2. Topologi Jaringan Yang Baru 


\section{PENUTUP}

\subsection{Kesimpulan}

Setelah melakukan perancangan jaringan, implementasi, analisa dan evaluasi pada Virtual Private Network menggunakan metode PPTP pada PT. Pelindo IV Makassar, maka dapat ditarik kesimpulan bahwa:

1. Perancangan Virtual Private Network menggunakan metode PPTP pada PT. Pelindo IV dapat berjalan dengan baik dan bisa diterapkan diseluruh cabangcabang Pelindo IV yang tersebar di Indonesia Timur.

2. Penerapan teknologi virtual private network menggunakan metode PPTP pada pelindo IV Makassar dapat dilakukan dengan mudah dan dengan konfigurasi yang mudah dipahami.

\subsection{Saran}

Berdasarkan penjelasan tentang perancangan dan implementasi Cisco Virtual Private Network menggunakan metode PPTP pada PT. Pelindo IV Makassar, maka dapat diberikan saran untuk pengembangan berikutnya yaitu sebagai berikut:

1. Pengembangan dapat dikembangkan dan diuji menggunakan perangkat lain yang memiliki performa sebanding dengan cisco seperti juniper, maupun, mikrotik dan perangkat lainnya.

2. Pengembangan model jaringan ini juga dapat menggunakan metode lain seperti L2TP, IPSec, DMVPN atau metode VPN lain yang proprietary dengan perangkat yang akan digunakan.

3. Pada Impelentasi yang sebenarnya, Virtual Private Network dapat di pasang dengan mudah disetiap cabang-cabang pelindo di Indonesia timur, dan kemudian menyediakan infrastruktur di pusat sebagai core koneksi yang akan melayani semua koneksi virtual private cabang.

\section{Daftar Pustaka}

[1]. Afrianto, Irawan.2014 "Virtual Private Network Sebagai Sistem Pengamanan Data Pada Jaringan Komputer." Studi Kasus Jaringan Komputer Unikom.

[2]. Dewannanta, Didha. 2013. Mengenal Software Simulator Jaringan Komputer GNS3. ilmukomputer.org.

[3]. Dewi, Yundari.2008 "Sekuriti Virtual Private Network." Universitas Sriwijaya.

[4]. Hutapea, Tommy PM. 2013. Virtual Private Network ( VPN ) Dynamic: Jawaban Keamanan untuk Intranet Pada Suatu Perusahaan. IlmuKomputer.Com.

[5]. Jaelani, Ahmad. 2014 Metode Penelitian.

https://student.unsika.ac.id/metode penelitian-owl/Tugas-

updates/metode-

metodedalammetodologipeneitian. Diakses 16 Mei 2015

[6]. Lagi, Alim. 2012.Pengertian dan Sejarah Cisco http://ekomputer.blogspot.com/2012/10/pe ngertian-dan-sejarah-cisco_4.html. Diakses 14 Mei 2015

[7]. Saputro, Toni. 2012 Point to Point Tunneling Protocol (PPTP). http://putrajatim.blogspot.com/201 2/04/point-to-point-tunnelingprotocol-pptp.html Diakses $12 \mathrm{Mei}$ 2015. 
[8]. Sukmaanji, Anjik. 2008 Jaringan Komputer. Yogyakarta: ANDI.

[9]. Syafrizal, Melwin. 2005 Pengantar Jaringan Komputer. Yogyakarta: ANDI.

[10]. Towidjojo, Hendra.2013. Mikrotik Kungfu. Jakarta: Jasakom 